\title{
PENGARUH BERBAGAI SISTEM TERHADAP SISTEM PENDIDIKAN ISLAM DI INDONESIA
}

\author{
Muhammad Syaifudin
}

\begin{abstract}
Education in Indonesia faces three great challengs, first, it is demanded to sustain the results of educational development, second, it is demanded to prefare competent human resources in order to be able in competition in global labour market, and finally, it is demanded to make changes and adaptations so that is able to realize a more democratic educational process. Islamic education as a system is much influenced by different systems that exist in life like sociocultural, economic, and political systems. Motif of each system give siginificant influences to educational motif, curricula, subject matters, teachers, and other components.
\end{abstract}

Key words: Islamic education, system and Islam

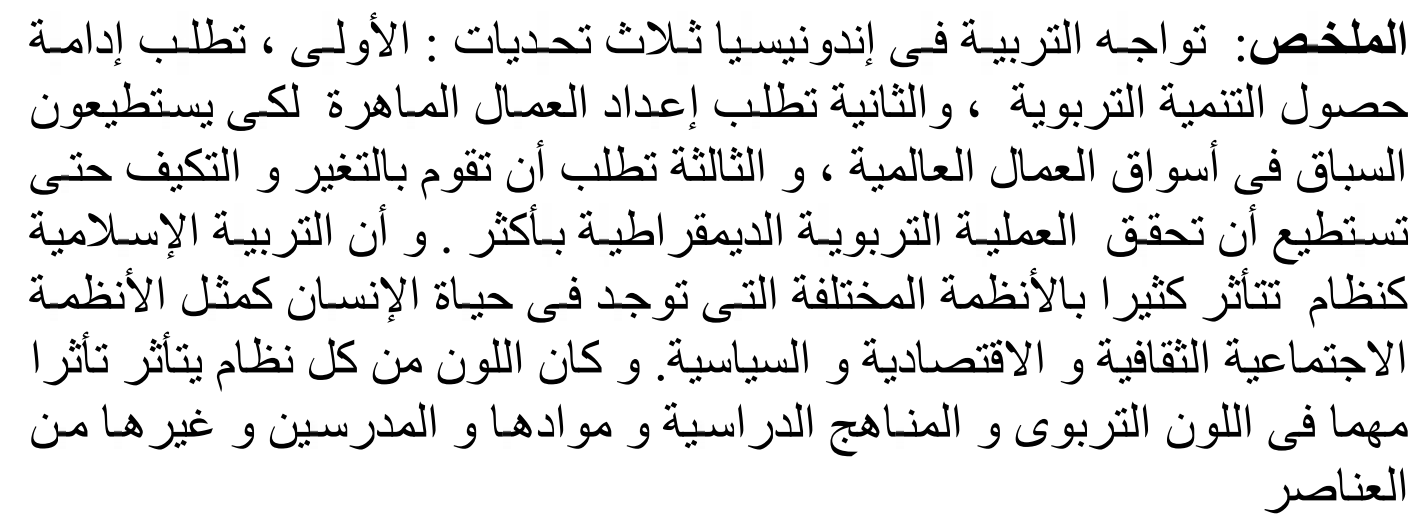

\section{Pendahuluan}

Sistem pendidikan secara umum dan sistem pengajaran khusus di negara dunia ketiga telah melalui perkembangan penting sepanjang seperempat abad terakhir. Namun, secara realitas, dihadapkan dengan berbagai gejala umum yang sangat sukar dan kritikal, diantaranya, dalam bidang ekonomi, rendahnya pendapatan perkapita dan pendapatan nasional, lemahnya produksi dalam negeri, pengangguran, kelaparan, kurangnya pemeliharaan kesehatan, dan tersebarnya buta huruf yang meluas, ketidakseimbangan berbagai sektor, dan dependensi dalam perdagangan, sains dan teknologi. Sedangkan gejala kesulitan dalam bidang sosial adalah ketegangan dan perselisihan yang timbul di antara berbagai negara dunia ketiga. Manakala dari segi budaya adalah dualisme dalam sistem pendidikan, pemikiran yang diwarisi dari zaman kolonial masih tetap bercokol dan memecahkan masyarakat tersebut di samping menimbulkan perselisihan pikiran dan politik yang menghabiskan tenaga dan potensinya. ${ }^{1}$ Dalam kehidupan sosial, dapat kita lihat pada revolusi dan krisis sosial yang berkecamuk di mana-mana terutama krisis perekonomian. Begitu juga pada peperangan dan kegoncangan politik di mana peperangan-peperangan tersebut 
yang biasanya membawa pada peperangan baru. Ini semua adalah bukti kegoncangan dan tidak adanya keseimbangan sosial.

Gerakan politik dan sosial internal pada abad delapan belas, sembilan belas, dan dua puluh di dunia Islam mengabaikan pendidikan Islam dan memberikan peluang pada gagasan sekular dan missioner eksternal yang menjadikannya pendidikan agama dalam artian sempit. Keragaman pandangan dunia dan interpretasi atas prinsip-prinsip Alqur'an tentang pendidikan berakibat ditekannya bentuk daripada hakikat dalam pendidikan kaum muslim. ${ }^{2}$

Pada awal abad XXI ini, dunia pendidikan di Indonesia menghadapi tiga tantangan besar. Tantangan pertama sebagai akibat dari krisis ekonomi, dunia pendidikan dituntut untuk dapat mempertahankan hasil-hasil pembangunan pendidikan yang telah dicapai. Kedua, untuk mengantisipasi era globalisasi, dunia pendidikan dituntut untuk mempersiapkan sumber daya manusia yang kompeten agar mampu bersaing dalam pasar kerja global. Ketiga, sejalan dengan diberlakukannya otonomi daerah, sistem pendidikan nasional dituntut untuk melakukan perubahan dan penyesuaian sehingga dapat mewujudkan proses pendidikan yang lebih demokratis, memperhatikan keberagaman kebutuhan/keadaan daerah dan peserta didik, serta mendorong peningkatan partisipasi masyarakat. ${ }^{3}$

Pendidikan Islam, ${ }^{4}$ sebagai usaha dan karya manusia, berkembang seiring dengan dinamika dan perubahan pranata sosial. Jika ia mampu mengikuti irama perubahan, maka ia akan "survive". Sebaliknya jika lamban, maka cepat atau lambat ia akan tertinggal dan ditinggalkan dilandasan. Oleh karena itu, tidak berlebihan jika dikatakan, bahwa eksistensi pendidikan Islam merupakan salah satu syarat yang mendasar dalam meneruskan dan mengekalkan kebudayaan manusia. Hal ini disebabkan karena pendidikan Islam, sebagai bagian dari sistem pendidikan nasional, memegang amanat untuk membina dan membangun manusia Indonesia seutuhnya. ${ }^{5}$ Bahkan secara tegas dinyatakan dalam amanat pasal 31 UUD 1945 dan perubahannya. ${ }^{6}$

Secara yuridis, posisi pendidikan Islam berada pada posisi yang strategis, baik pada UUSPN No. 2 Tahun 1989 maupun UUSPN No. 20 Tahun 2003.7 Mencermati pasal-pasal yang terdapat pada UUSPN tersebut, terlihat bahwa pendidikan agama (Islam) ${ }^{8}$ tidak hanya menekankan pada pengembangan IQ, tetapi EQ dan SQ secara harmonis. Artinya, bahwa pendidikan Islam harus mampu melahirkan insan yang beriman-takwa, berakhlak mulia, dan memiliki kualitas intelektual yang tinggi. Urutan prioritas pendidikan Islam dalam upaya pembentukan kepribadian muslim, sebagaimana diilustrasikan berturut-turut dalam Alqur'an surat Luqman, mulai ayat 13 dan seterusnya adalah: (1) Pendidikan keimanan kepada Allah SWT, (2) Pendidikan Akhlak al-Karimah, dan (3) Pendidikan Ibadah. ${ }^{9}$

Selanjutnya, dalam kasus di Indonesia, sistem pendidikan Islam ${ }^{10}$, yang selama ini diidentikkan dengan sistem pesantren dan madrasah, dalam perkembangannya dipengaruhi oleh berbagai sistem yang berlaku dalam kehidupan baik sistem sosial-budaya, ekonomi, dan politik. Sehingga hitam putihnya lembaga pendidikan Islam salah satunya ditentukan oleh berbagai sistem tersebut. Oleh karena itu, makalah ini berusaha akan membahas berbagai sistem tersebut dan implikasinya terhadap sistem pendidikan Islam. 


\section{Sistem Sosial Budaya}

a) Pengertian

Manusia sebagai "al-Insan" yang memiliki akal-pikiran mengembangkan budaya $^{11}$ yang berdampak luas terhadap kehidupan dan lingkungan di permukaan bumi. Kemampuan akal-pikiran yang dapat dinyatakan juga sebagai kemampuan budaya, memiliki makna yang tinggi bagi manusia sebagai makhluk hidup, yang membawa kenyataan dalam kehidupan seperti yang kita alami dewasa ini. Aspek-aspek atau komponen-komponen materi (ruang, alam semesta, bangunan, pakaian, peralatan), dengan non-materi (pengetahuan, kepercayaan, nilai, sikap, makna, hirarki, agama ${ }^{12}$, peranan), merupakan suatu sistem yang disebut sistem budaya. ${ }^{13}$

Sistem budaya merupakan rangkaian hubungan komponen-komponen budaya sebagai ungkapan prilaku, perbuatan, dan tindakan manusia sebagai makhluk budaya. Namun demikian, dalam mekanisme budaya tersebut, tidak terpisahkan dari hubungan antara manusia sebagai makhluk sosial yang menhubungkan antar individu, antara individu kelompok, dan antara kelompok dengan kelompok manusia lainnya. Di sini terbentuk suatu tatanan yang kita konsepkan sebagai sistem sosial. Sistem ini terbentuk, sebagai akibat hubungan sosial antar komponen-komponen sosial (individu, kelompok) dalam bentuk tindakan, perbuatan dan prilaku pendukungnya. ${ }^{14}$ Sementara Nasikun mendefinisikan bahwa sistem sosial pada dasarnya tidak lain adalah suatu sistem tindakan-tindakan. Ia terbentuk dari interaksi sosial yang terjadi di antara berbagai individu, yang tumbuh dan berkembang tidak secara kebetulan, melainkan tumbuh dan berkembang di atas standar penilaian umum yang disepakati bersama oleh para anggota masyarakat. Yang paling penting di antara berbagai standar penilaian umum tersebut, adalah apa yang kita kenal sebagai norma-norma sosial. Norma-norma sosial itulah yang sesungguhnya membentuk struktur sosial.15 Dalam sistem budaya inilah manusia belajar, berkreasi, berinovasi, berilmu, dalam suatu tatanan kehidupan yang disebut kehidupan berbudaya.

Dalam sistem budaya, melekat pada diri manusia sebagai komponennya, yaitu filsafat, humaniora, dan ilmu pengetahuan, sebagai hasil renungan mendalam dari manusia sendiri, menjadi landasan kearifan dan kebijakan. Tanpa landasan filsafat, hidup dan kehidupan manusia menjadi tidak menentu arahnya. Dengan demikian, kedudukan filsafat dalam sistem budaya, merupakan salah satu landasan hasil pemikiran yang mendalam dari manusia sendiri, terutama manusia yang memiliki kadar dan derajat sebagai filosof.

Dari definisi di atas dapat dipahami bahwa sistem sosial-budaya merupakan mekanisme hubungan tindakan, perbuatan, dan prilaku individu berdasarkan standar norma yang disepakati bersama oleh para anggota masyarakat.

b) Karakteristik

Dalam pendekatan ini secara implisit terdapat perbedaan dua tipe ideal, antara masyarakat tradisional dan masyarakat modern. Untuk mendefinisikan masyarakat tradisional tidaklah mudah, karena kategorinya biasanya meliputi organisasi tradisional yang sederhana sekaligus imperium yang kompleks. Tipe 
ideal sebuah masyarakat tradisional paling tepat diterapkan pada kelompokkelompok tribe terisolasi yang relatif kecil dan tidak benar-benar bisa diterapkan ntuk situasi aktual yang ada saat ini atau ada masa lampau di dunia non-Barat. Oleh karena itu, seorang ahli berpendapat bahwa sebuah konstruksi baru, 'masyarakat feodal', mungkin lebih sesuai. Pada dasarnya masyarakat feodal jauh lebih kompleks daripada masyarakat tradisional. Masyarakat feodal memiliki strata yang lebih rendah. Mereka sebagian besar terdiri dari masyarakat petani yang tinggal di pedesaan dan menggunakan teknologi rendah, ditambah beberapa tenaga terampil, di samping kelompok berkuasa yang berbasis di kota yang terdiri dari birokrat, pendeta, sarjana, tuan tanah, dan prajurit, dengan kombinasi yang beragam. Pola stratifikasi ini merupakan pola bifurkatif, dengan pengaturan yang memisahkan dan berbeda dari sisi penampilan, bahasa, dan sikap masyarakat; tetapi mobilitas sosial di antara kedua strata tersebut minim. Masyarakat feodal juga ditandai dengan adanya institusi administrasi, kegamaan dan pendidikan yang sudah jauh dikembangkan, yang digunakan oleh kelas yang berkuasa untuk mengabadikan posisinya di struktur masyarakat. Bagaimanapun, ada kesamaan yang penting antara masyarakat feodal dan tradisional; keduanya adalah masyarakat yang statis, lugu, dan ditandai dengan tingkat keharmonisan internal yang tinggi.16

Masyarakat modern benar-benar berbeda. Mereka bercirikan egalitarianisme dan tingkat mobilitas sosial tinggi. Institusi-institusinya sangat berbeda, khusus dan rasional. Tatanan ekonomi, politik, dan sosialnya terus-menerus mengalami perubahan, dan kriteria keberhasilan menentukan status. Bagaimanapun, perbedaan utama di antara kedua tipe masyarakat itu adalah sifat dinamis dari masyarakat modern jika dibandingkan dengan karakter masyarakat feodal yang relatif statis. Di sisi lain, sistem modern memiliki keluwesan dan kemampuan adaptasi untuk mengatasi perubahan yang demikian cepat dan mendasar di semua sektor masyarakat. ${ }^{17}$

Memang tidak semua nilai tradisional menghambat modernisasi. Malahan ada yang harus dipertahankan dan dikembangkan untuk memberikan kondisi dan model pribumi dalam pembangunan dan modernisasi ini. Bahwa kita tidak menjadikan modernisasi ini sebagai westernisasi, haruslah terlihat dari usaha untuk mempertahankan dan mengembangkan sikap, pola dan nilai yang tradisional. Apa yang berkembang sekarang yaitu semangat dan nilai gotongroyong, kekeluargaan, tepo seliro, keseimbangan, dan sebagainya, adalah usaha untuk memantapkan tradisionalitas tersebut.

Yang harus ditinggalkan adalah sikap atau pola yang berdasarkan nilainilai tradisional yang tidak tepat lagi, misalnya feodalisme. Feodalisme, jelas tidak mendorong berkembangnya prinsip egalitarian. Preferensinya adalah pada kelompok anggota masyarakat tertentu. Kesempatan mengembangkan mobilitas, tidak sama. Ada yang disebut priveleg few dalam rangka sikap ini, perlu kita berikan perhatian pada sikap apa yang disebut sebagai solidaritas sempit. Solidaritas memang baik apabila dia ditujukan kepada anggota masyarakat yang masih harus ditingkatkan kehidupannya. Solidaritas mendorong berkembangnya mobilitas masyarakat karena tekanannya pada segi kemanusiaan. Sikap kebersamaan atau solider pada sesama, justeru mendorong, membangun dan meningkatkan mobilitasnya. Yang tidak tepat adalah 
solidaritas yang hanya didasarkan pada kepentingan-kepentingan tertentu dan terbatas pada lapisan horisontal maupun golongan vertikal, atau terbatas pada kelompok elite tertentu. Solidaritas sempit ini jelas menghambat mobilitas pembangunan. ${ }^{18}$

Dari kedua karakteristik sistem sosial-budaya masyarakat tersebut dapat dipahami bahwa bagaimanapun berkembang pesatnya suatu zaman, tipe-tipe masyarakat seperti yang telah disebut di atas tetap eksis baik tipe masyarakat tradisional maupun modern. Tipe tersebut lebih cenderung kepada pola fikir dan bertindak yang akan berimplikasi terhadap sistem pendidikan Islam.

c) Implikasinya Terhadap Sistem Pendidikan Islam

Globalisasi acapkali difahami sebagai suatu kekuatan raksasa yang mempengaruhi tata kehidupan dunia secara menyeluruh, simultan, dan berdampak multiplayer effects. Dengan pengaruh globalisasi, dunia terasa menjadi kecil dan transparan. Hampir tidak ada rahasia suatu negara yang tidak diketahui oleh negara lain. Globalisasi juga menjadikan kelompok kecil cenderung mendunia dan melampaui batas-batas negara, budaya, ekonomi, bahkan agama dan ras. Entitas semakin mengecil tetapi kerja semakin profesional. Masyarakat berkembang menuju kowledge society, yakni masyarakat akademik atau post-capital society. Ciri utama masyarakat ini adalah persaingan bebas. Tentu saja, watak dasar masyarakat seperti ini berbeda secara esensial dengan kapitalisme, dari masalah struktur sampai masalah sosial. Misalnya, dalam kapitalisme kekuasaan dipegang oleh pemilik modal (kapital) dan pemilik alat-alat produksi. Sedangkan dalam knowledge society puncak kesuksesan atau untuk menjadi sukses (berprestasi) adalah mereka yang educated person. Orang terus-menerus mencari ilmu untuk merebut dan menguasai sains dan teknologi. Dengan demikian penghargaan tertinggi bukan pada ijazah atau status, tetapi kemampuan belajar yang maksimal. Dalam tata kehidupa modern, siapa yang cerdas dan memiliki informasi, serta mampu mengelola komunikasi, dialah yang berkuasa dan memimpin kehidupan ini. ${ }^{19}$

Dari sini kita menyadari bahwa biang keladi dari semua itu adalah akal atau pemikiran. Barangkali satu-satunya faktor terpenting penyebab terjadinya kerusakan dan stagnasi pendidikan dan pemikiran adalah batasan Islam tentang ilmu pengetahuan yang dapat diterima. Meskipun ilmu pengetahuan sangat dihargai dan pencarian ilmu itu selalu dianggap penting (kedua faktor yang memungkinkan Islam memberikan sumbangan khusus bagi peradaban dunia), batasan yang benar dan pandangan yang mendasarinya tidak sesuai dengan permasalahan. Kebebasan berfikir tidak pernah menjadi nilai sentral kebudayaan dan masyarakat muslim; penekanannya terletak pada upaya memperoleh sebanyak mungkin kebijaksanaan yang bisa dipercaya. ${ }^{20}$

Seperti dikemukakan di atas, masalah pendidikan tidak lepas dari pengaruh pertumbuhan internasional secara global. Masalah pengaruh globalisasi ini berada di seputar ketidakseimbangan kekuatan dan kemajuan antara kelompok negara-negara utara dan selatan. Atau dalam skala yang lebih kecil antara lapisan masyarakat dalam suatu negara, di mana lapisan atas dan kaya memegang posisi membantu dan mengatur karena mereka mampu menjangkau pendidikan dalam rangka menguasai informasi dan teknologi canggih. Sementara lapisan bawah dan miskin berada pada posisi dibantu dan 
diatur karena mereka terperangkap dalam kebodohan dan kemiskinan disebabkan tidak terjangkaunya pendidikan bagi mereka.

Kenyataan di atas seiring dengan munculnya sekolah-sekolah favorites dan tidak favorites. Semua itu, selain memperlebar jurang perbedaan antara lapisan masyarakat atas dan bawah, tetapi juga menyuburkan semakin besarnya kecemburuan Sosial terhadap kelompok atas, sehingga pada akhirnya dapat memudarkan identitas nasional yaitu masyarakat yang senantiasa hidup dalam suasana kekeluargaan, rukun, damai dan saling tolong-menolong.

Selanjutnya, dalam kaitan karakteristik sistem sosial-budaya masyarakat (tradisional dan modern) dan implikasinya terhadap sistem pendidikan Islam, dalam hal ini pesantren, secara realitas dahulu masyarakat pedesaan yang identik dengan pola fikir tradisionalnya beranggapan bahwa yang dikatakan pendidikan Islam itu adalah belajar membaca Alqur'an dan ilmu agama ansich dan masyarakat perkotaan yang identik dengan pola fikir modern cenderung menyekolahkan anaknya ke sekolah umum. Seiring dengan perkembangan zaman, orientasi tersebut telah berubah. Masyarakat tradisional saat ini tidak hanya membutuhkan pendidikan agama dalam makna yang sempit, tetapi pendidikan agama yang komprehensif karena tuntutan zaman demikian pesat dan kompetetitif. Hal ini ditandai dengan munculnya pesantren terpadu atau modern yang tidak hanya mengajarkan ilmu-ilmu keislaman, tetapi juga sains dan teknologi. Sebaliknya, masyarakat modern tidak hanya membutuhkan pendidikan sains dan teknologi, tetapi pendidikan keimanan, ibadah dan akhlak karena semakin intensnya terjadi kemerosotan akhlak di kalangan anak-anak mereka. Hal ini ditandai dengan munculnya lembaga pendidikan umum yang bersifat plus seperti SD-Plus, SMP-Plus dan SMA-Plus yang mengintegrasikan antara pengajaran sains dan teknologi dengan nilai-nilai ke-Islaman secara komprehensif.

Dengan demikian dapat dipahami bahwa corak sosial budaya suatu masyarakat akan memberikan warna tersendiri terhadap sistem pendidikan yang berlaku dalam masyarakat itu sendiri.

\section{Sistem Ekonomi}

a) Pengertian

Sistem ekonomi ${ }^{21}$ merupakan aturan-aturan untuk meyelenggarakan kebutuhan hidup manusia dalam rumah tangga, baik dalam rumah tangga rakyat (volkshuishouding) maupun rumah tangga negara (staatshuishouding). ${ }^{22}$

Masalah-masalah pokok ekonomi menurut para pakar mencakup antara lain: (a) Jenis dan jasa yang diproduksi serta sistemnya, (b) Sistem distribusi (untuk siapa barang jasa itu), (c) Efisiensi penggunaan faktor-faktor produksi, (d) Inflasi, resesi, dan depresi, dan (e) Dan lain-lain. ${ }^{23}$

Dari definisi di atas dapat dipahami bahwa sistem ekonomi sangat erat kaitannya dengan kehidupan manusia yaitu menyangkut pemenuhan kebutuhan pokok manusia yang meliputi pangan, sandang dan papan serta kebutuhan lainnya. Sekiranya tidak ada suatu aturan/sistem yang mengikat dalam pemenuhan kebutuhan tersebut, maka akan terjadi ketidakteraturan. Dengan 
demikian dapat juga dikaatakan bahwa sistem ekonomi berkembang seiring dengan perkembangan kehidupan manusia dan menjadi corak sebuah masyarakat yang menganutnya.

b) Karakteristik

Uraian mengenai karakteristik sistem ekonomi akan dibagi ke dalam dua bagian besar, yaitu: Pertama, sistem ekonomi Islam yang berangkat dari kesadaran tentang etika (ethical economy), sedangkan sistem ekonomi lain, baik kapitalisme maupun sosialisme, berangkat dari kepentingan (interest). Mengenai etika Islam dalam ekonomi menurut Syed Nawab Haider Naqwi seperti yang dikutip Kuntowijoyo merujuk kepada empat aksioma etika yaitu: Tauhid, keseimbangan, kehendak bebas, dan pertanggungjawaban. ${ }^{24}$

Selanjutnya, ekonomi Islam ditegakkan oleh semangat hubb wa al-ihsan (cinta-mencintai dan berbuat kebajikan), berjiwa infaq wa al-birr (berani berkorban dan membuat kebajikan), mempunyai karakter itsar (sanggup menderita karena mengutamakan orang lain), memegang sistem ta'awun wa syikah (hidup kolektif dalam pencaharian dan pendistribusian rezeki), sehingga tidak mungkin timbul kerakusan dan ketamakan di pihak yang mampu dan rasa putus asa bagi pihak yang tidak mampu. Ringkasnya, ekonomi dalam Islam mengandung dasar-dasar keutamaan dan kebahagiaan serta kemakmuran bersama dan menghilangkan jurang pemisah yang membedakan antara si kaya dan si miskin. 25

Jika kita simak dengan seksama karakteristik yang mendasari ekonomi Islam di atas, maka ibadah zakat yang merupakan rukun ketiga dari rukun Islam dipandang sebagai salah satu sistem ekonomi Islam yang dampaknya langsung oleh kelompok yang berhak menerimanya baik individu maupun kepentingan umum dari masyarakat dan negara, termasuk masalah pendidikan Islam.

Dengan demikian dapat dipahami bahwa sistem ekonomi Islam sangat menekankan kepada persoalan etika (akhlak) para pelaku ekonomi karena tidak hanya terkait dengan sesama manusia, tetapi juga terkait dengan pertanggungjawabannya dihadapan Tuhan.

Kedua, sistem ekonomi Pancasila yang secara ideal berlandaskan kepada Pancasila dan secara struktural kepada UUD 1945. Pada pasal 33 UUD 1945 ditegaskan bahwa asas ekonomi adalah kebersamaan dan kekeluargaan. Selanjutnya, dalam pasal itu juga disebutkan bahwa cabang-cabang produksi yang penting bagi negara dan yang menguasai hajat hidup orang banyak dikuasai oleh negara. Juga disebutkan penguasaan negara atas bumi dan air serta kekayaan alam yang ada didalamnya. ${ }^{26}$

Jika kita simak dengan seksama, terdapat persamaan antara kedua sistem tersebut yaitu penekanannya pada aspek etika dalam melaksanakan nilai-nilai ekonomi dalam kehidupan sehari-hari. Dampaknya terhadap sistem pendidikan Islam dapat dirasakan secara langsung, sehingga dapat dikatakan bahwa maju mundurnya lembaga pendidikan Islam juga sangat dipengaruhi oleh aspek ekonomi atau anggaran pendidikan.

c) Implikasinya Terhadap Sistem Pendidikan Islam

Setiap negara di dunia berusaha mencapai tingkat pertumbuhan ekonomi yang pesat, dan mendukung investasi besar-besaran dalam pendidikan dengan keyakinan bahwa sekolah formal merupakan variabel utama yang menentukan 
tingkat dan kecepatan perkembangan ekonomi. Secara umum para peneliti menyimpulkan bahwa ada hubungan positif antara pembentukan modal manusia (yakni pendidikan sebagai komponen utama) dengan pertumbuhan ekonomi.

Pendidikan dalam operasionalnya tidak dapat dilepaskan dari masalah biaya atau moneter. Biaya pendidikan yang dikeluarkan untuk penyelenggaraan pendidikan tidak akan tampak hasilnya secara nyata dalam waktu relatif singkat. Oleh karena itu, uang yang dikeluarkan oleh pemerintah, masyarakat, maupun orang tua (keluarga) untuk menghasilkan pendidikan atau membeli pendidikan bagi anaknya harus dipandang sebagai investasi SDM (Human Capital). Uang yang dikeluarkan di bidang pendidikan sebagai bentuk investasi pada periode tertentu, di masa yang akan datang harus dapat menghasilkan keuntungan (benefit) atau manfaat, baik dalam bentuk uang (finansial) maupun non-finansial.

Selanjutnya, Ramayulis mengatakan bahwa akhir-akhir ini terjadi pergeseran pandangan masyarakat terhadap pendidikan seiring dengan tuntutan masyarakat (sosial demand) yang berkembang dalam sakala yang lebih makro. Kini, masyarakat melihat pendidikan tidak lagi dipandang hanya sebagai bentuk pemenuhan kebutuhan terhadap perolehan pengetahuan dan keterampilan dalam konteks waktu sekarang saja, tetapi di sisi lain, pendidikan dipandang sebagai bentuk investasi, baik modal maupun manusia (human and capital investmen) untuk membantu meningkatkan keterampilan hidup (life skill) dan pengetahuan (knowledge) sekaligus mempunyai kemampuan produktif di masa depan yang diukur dari tingkat penghasilan yang diperolehnya. ${ }^{27}$ Oleh karena itu, pembiayaan pendidikan tidak cukup diperoleh dari pemerintah/negara saja, tetapi yang lebih utama sebenarnya adalah dari lembaga dan dari masyarakat. Dari hasil penelitian terdapat korelasi positif antara kualitas lulusan dengan dana pendidikan. Sehubungan dengan hal tersebut, maka lembaga pendidikan Islam harus mencari dana yang halal di antaranya: (1) Membentuk badan usaha atau koperasi, (2) Bekerjasama dengan negara-negara Islam yang kaya sumber daya alamnya, (3) Mengusahakan sumber dana dari waqaf prosduktif, (4) Menyediakan dana abadi, (5) Membentuk Lembaga ZIS, dan (6) Mencari sumbangan dan bantuan lain yang tidak mengikat. ${ }^{28}$

Terkait dengan problema pendidikan Islam (kasus di Minang Kabau), salah satunya adalah bahwa lembaga pendidikan Islam masih kekurangan dana dalam penyelenggaraan proses belajar-mengajar, membangun sarana dan prasarana serta alat-alat pengajaran dan perkantoran, mulai dari tingkat Ibtidaiyyah, Tsanawiyah, Aliyah, dan Perguruan Tinggi, baik negeri maupun swasta. Baru di era reformasi ada sedikit gambaran dari pemerintah untuk meningkatkan anggaran pendidikan ibtidaiyyah, tasanawiyah, aliyah dan PTAIN, sehingga sama atau mendekati subsidi yang diberikan kepada pendidikan umum. ${ }^{29}$

Dengan demikian dapat dipahami bahwa sistem ekonomi yang berkembang dalam suatu kelompok masyarakat akan memberikan warna tertentu terhadap sistem pendidikan yang berlaku dalam masyarakat itu sendiri. Sebagai contoh, jika sistem zakat dan pemberdayaannya dapat dilakukan secara konsekuen, maka tidak akan pernah terjadi lembaga pendidikan Islam yang kesulitan untuk membiayai pelaksanaan proses pembelajaran. Hal ini dikarenakan salah satu kelompok yang dapat menerima zakat untuk 
kepentingan umum masyarakat dan negara dalam rangka berjuang meninggikan kalimat Allah adalah Fisabilillah.

\section{Sistem Politik}

a) Pengertian

Sistem politik ${ }^{30}$ merupakan pola hubungan masyarakat yang dibentuk berdasarkan keputusan-keputusan yang sah dan dilaksanakan dalam masyarakat itu. Sistem politik dibedakan dari sistem lain oleh empat cirri khas, pertama, daya jangkau yang universal, meliputi semua anggota, kedua kontrol mutlak atas pemakaian kekerasan fisik, ketiga, hak membuat keputusankeputusan yang mengikat dan diterima sebagai absah, dan keempat, keputusannya bersifat otoritatif, artinya menyandang daya pengabsah dan kerelaan yang besar. Karena keempat ciri khas tersebut adalah juga ciri khas negara, maka istilah sistem politik umumnya dipakai sebagai nama kolektifitas hubungan dari suatu negara. ${ }^{31}$

Selanjutnya, sistem politik itu meliputi (1) sistem pemerintahan, dasardasar pemerintahan, (2) segala urusan dan tindakan (kebijaksanaan, siasat dan sebagainya) mengenai pemerintahan atau terhadap negara lain, dan (3) Kebijakan, cara bertindak (dalam meghadapi atau menangani suatu masalah). ${ }^{32}$

Dengan demikian dapat dipahami bahwa politik sebagai sebuah sistem sangat erat kaitannya dengan pola hubungan masyarakat dengan negara. Wujud dari hubungan itu adalah lahirnya sebuah istilah demokrasi. Dalam prakteknya, demokrasi sebagai sebuah sistem bagi sebuah masyarakat/negara akan memebrikan corak/karakteristik terhadap segala aspek kehidupan yang salah satunya adalah aspek pendidikan.

b) Karakteristik

Dalam realitasnya, Indonesia sebagai sebuah negara dapat dipastikan menganut sistem politik yang bermuara pada demokrasi yang memiliki karakteristik tersendiri. Saat ini, istilah demokrasi telah diterima oleh hampir seluruh pemerintahan di dunia, bahkan pemerintahan otoriter pun menggunakan istilah "demokrasi" untuk mengkarakterisasikan rezim dan aspirasi mereka. Demokrasi memang merupakan slogan politik kontemporer. Akibatnya adalah menjamurnya pengertian "demokrasi", seperti "Demokrasi Liberal", "Demokrasi Terpimpin", "Demokrasi Kerakyatan", "Demokrasi Sosialis", dan lain sebagainya. ${ }^{33}$

Selanjutnya, Robert A. Dahl menunjukkan tujuh kritaeria yang harus ada dalam sistem yang demokratis yaitu: Pertama, kontrol atas keputusan pemerintah mengenai kebijakan secara konstitusional diberikan pada para pejabat yang dipilih. Kedua, para pejabat dipilih melalui pemilihan yang teliti dan jujur dimana paksaan dianggap sebagai sesuatu yang tidak umum. Ketiga, secara praktis semua orang dewasa mempunyai hak untuk memilih dalam pemilihan pejabat. Keempat, Secara praktis semua orang dewasa mempunyai hak untuk mencalonkan diri pada jabatan-jabatan di pemrintahan, walaupun batasan umur untuk nenduduki jabatan mungkin lebih ketat ketimbang hak pilihnya. Kelima, rakyat mempunyai hak untuk menyuarakan pendapat tanpa ancaman hukuman 
yang berat mengenai berbagai persoalan politik yang didefinisikan secara luas, termasuk mengkritik para pejabat pemerintahan, rezim, tatanan sosio-ekonomi dan ideologi yang berlaku. Keenam, rakyat mempunyai hak untuk mendapatkan sumber-sumber informasi alternatif. Lebih dari itu, sumber-sumber informasi alternatif yang ada dan dilindungi oleh hukum. Ketujuh, untuk meningkatkan hak-hak mereka, termasuk hak-hak yang dinyatakan di atas, rakyat juga mempunyai hak untuk membentuk lembaga-lembaga atau organisasi-organisasi yang relatif independen, termasuk berbagai partai politik dan kelompok kepentingan yang independen. ${ }^{34}$

Dari uraian di atas dapat dipahami bahwa demokrasi sebagai sub sistem politik sangat memperhatikan aspek rakyat yang menerima dampak dari kebijakan yang dilahirkan oleh sebuah negara sehingga terjadi pola hubungan yang harmonis antara negara dengan rakyat dalam berbagai aspek kehidupan. Hal ini juga terlihat pada implikasi dari sistem tersebut terhadap sistem pendidikan Islam.

c) Implikasinya Terhadap Sistem Pendidikan Islam

Dalam perspektif politik, pelaksanaan pendidikan agama (Islam) di sekolah termasuk di perguruan tingginya mengalami pasang surut seiring dengan pemegang kekuasaan dan suasana politik nasional. Pasang surut itu dapat dilihat dari posisi, isi dan visi serta makna pendidikan agama dalam sistem pendidikan yang sedang berlangsung.

Acapkali pendidikan agama hanya menempati posisi pinggiran, sebagai suplemen. Sementara formalitas dan isi serta visinya didominasi bahkan direduksi oleh kepentingan politik. Di sisi lain, pendidikan agama juga menjadi komponen pokok dari sistem pendidikan yang berkembang dalam posisi yang lebih kualitatif baik dalam konsep maupun pelaksanaannya. Pendidikan agama bukan sekedar pendidikan tentang agama atau pewarisan nilai-nilai agama, dalam praktek da sejarahnya justeru sarat dengan muatan politik bahkan juga mencerminkan haluan politik yang sedang berkembang. ${ }^{35}$

Karakter sistem politik, khususnya karakter kaum elitnya menjadi satu variabel yang kritis. Sekalipun ada interaksi yang jelas antara politik dan segmen-segmen lain dari tatanan masyarakat dan konfigurasi khusus kekuatan di dalam masyarakat harus dipertimbangkan sebagai penghambat kemampuan pemimpin untuk mengambil kebijakan-kebijakan tertentu, melalui pilihan dan tindakan politislah institusi ekonomi, pendidikan dan sebetulnya institusi politik itu sendiri dibentuk secara fundamental. Kebijakan-kebijakan pendidikan secara langsung berkaitan dengan persoalan yang lebih luas dari pembuatan kebijakan di masyarakat dan keputusan-keputusan khusus yang diambil untuk beberapa masalah, seperti siapa yang akan memasuki sekolah, apa yang akan dipelajari, dan bagaimana mereka memanfaatkan, yang semuanya pasti mencerminkan distribusi kekuasaan, unsur-unsur pendukung yang dimiliki rezim tertentu, orientasi ideologisnya, tingkat perkemnbangan politiknya dan sebagainya.

Selain itu, keputusan-keputusan politik jelas dibutuhkan jika sistem pendidikan disusun sedemikian rupa sehingga sejalan dengan tujuan nasional dan jika struktur yang melingkupinya mendukung dan memperkuat, tetapi seperti yang kita lihat, tidak semua masyarakat memiliki kepemimpinan yang berkeinginan dan mampu menyerap dan mengimplementasikan secara sukses 
kebijakan-kebijakan yang dibutuhkan. Namun, para pembuat kebijakan di setiap masyarakat yang sedang berkembang telah mengakui potensi pendidikan sebagai kekuatan yang integratif dan memasyarakat, serta telah berusaha memanfaatkannya denga kaca mata ini. Sistem pendidikan formal diharapkan berfungsi tidak hanya sebagai sarana untuk mencapai pertumbuhan ekonomi, tetapi juga sebagai agen pemasyarakatan modernitas dan kebangsaan. Bermacam-macam kelompok yang membentuk negara diintegrasikan ke dalam pemahaman umum tentang kebangsaan, dan tema-tema politik dan ideologis yang ditemukan dan secara relatif eksplisit diartikulasikan dalam setiap kurikulum. ${ }^{36} \mathrm{Hal}$ ini mengindikasika bahwa sistem pendidikan bukanlah sesuatu yang dapat berdiri sendiri tanpa adanya sistem politik.

1) Pendidikan Agama Dalam Sejarah

Pada zaman koloial Belanda, pendidikan agama tidak diberikan di sekolah. Hal ini dapat dimengerti karena pemerintah Hindia Belanda mengembangkan pendidikan yang netral agama (sekuler), walaupun sebenarnya Belanda sangat berkeinginan memasukkan pendidikan agama Kristen.

Dalam perkembangan kemudian, demi menjaga citranya di kalangan mayoritas penduduk pribumi dan raja-raja muslim yang "berkuasa", akhirnya Belanda dapat menunjukkan sikap netralnya. ${ }^{37}$ Selanjutnya, atas desakan tokohtokoh Islam, penidikan agama akhirnya diberikan di luar jam pelajaran resmi dan guru agama tidak mendapat gaji dari pemerintah.

Pada zaman jepang, pelaksanaan pendidikan agama relatif lebih baik dimana pelaksanaan pendidikan agama mendapat persetujuan dari Kantor Agama Pusat dan guru agama digaji oleh pemerintah daerah setempat. Artinya posisi pendidikan agama sangat bergantung pada tuntutan masyarakat setempat dan kesediaan pemerintah lokal untuk memberikan gaji. Seringkali guru agama tidak mendapatkan gaji sama sekali tetapi juga ada juga yang mendapatkan gaji dari swadaya masyarakat setempat atau dipungutkan dari gaji guru yang lain. ${ }^{38}$

Pada masa kemerdekaan, keadaan pendidikan agama lebih baik terutama setelah dibentuknya Departemen Agama sebagai hasil bargaining (tawarmenawar) politik umat Islam setelah dihapuskannya Piagam Jakarta. ${ }^{39}$ Departemen Agama mengusulkan tiga hal: (1) memberikan pengajaran agama di sekolah negeri dan partikulir, (2) memberi pengetahuan umum di madrasah, dan (3) mengadakan Pendidikan Guru Agama (PGA) dan Pendidikan Hakim Agama Islam Negeri (PHIN), sekarang IAIN. Dalam Undang-Undang Pendidikan Nasional No. 4 Tahun 1950 jo. UUPN no. 12 Tahun 1954 juga ditetapkan bahwa sekolah-sekolah negeri diselenggarakan pelajaran agama dengan catatan orang tua murid yang menetapkan keikutsertaan anaknya. Dengan demikian, secara dejure posisi pendidikan agama relatif kuat atau minimal memiliki kekuatan hukum.

Namun demikian, dalam pelaksaannya ternyata masih mengalami banyak hambatan sejalan dengan pergumulan ideologi dan politik yang terjadi. Ki Hajar Dewantoro sebagai Menteri Pendidikan Pengajaran dan Kebudayaan (PP dan K) pada waktu itu misalnya memasukkan pendidikan agama sebagai bagian dari pendidikan susila yang berisi tentang pendidikan budi pekerti. Dengan demikian, pendidikan agama pada masa itu hanya menempati posisi suplemen yaitu pelengkap dari pendidikan kesusilaan. Keadaan ini berlangsung sampai 
masa-masa akhir Orde Lama, di mana PKI menjadi kekuatan politik yang dominan dalam pembuatan keputusan-keputusan politik, sehingga pendidikan agama semakin terpojok.

Pendidikan agama benar-benar memiliki posisi yang kuat setelah Orde Baru yang berhaluan anti komunis mengambil alih kekuasaan. Kebijakan tentang pendidikan agama dilaksanakan berdasarkan pokok kebijakan: (1) Pemerintah Orde Baru memang lebih codong kepada Islam, karena hanya Islamlah yang benar-benar anti komunis. Diwajibkannya pendidikan agama di semua jenjang dan jenis pendidikan, merupakan rangkaian pemberantasan komunisme sampai ke akar-akarnya; (2) Sebagai ucapan terima kasih kepada umat Islam yang bersama ABRI telah menyelamatkan ideologi negara Pancasila dan Negara Kesatuan Republik Indonesia dari G.30.S. PKI yang hendak mengganti Pancasila dengan ideologi komunisme; (3) Sudah menjadi kewajiban pemerintah untuk memenuhi tuntutan rakyat yang secara obyektif sangat memerlukan pendidikan agama. Sebab fungsi pemerintah di samping mengemban amanat yang bersifat politis juga amanat di bidang edukatif termasuk di dalamnya pendidikan agama.

Walaupun pendidikan agama secara resmi dilaksanakan secara penuh, pelaksanaannya sangat bergantung hubungan politik dan kondisi yang berkembang dalam kurun waktu tertentu. Oleh karena itu dalam suasana hubungan umat Islam terutama kelompok santri dengan pemerintah masih terkesan mengalami kesenjangan (jarak politik), posisi pendidikan agama kurang lebih serupa. Oleh karena itu posisi pendidikan agama benar-benar unik. Di satu sisi pendidikan agama sangat diperlukan sebagai media pemberantas dan penangkal Komunisme, sementara di sisi lain pendidikan agama diharapkan tidak dijadikan alat politik kelompok santri, terutama dalam menjadikan Islam sebagai ideologi politik dan bernegara di samping Pancasila.

Atas dasar itulah, Pemerintah Orde Baru melalui Golkar sebagai mesin politiknya senantiasa mengadakan kontrol terhadap pendidikan agama mulai dari kurikulumnya sampai pada pelaksanaannya terutama mengenai kualifikasi gurunya. Dan bahkan lebih dari itu, Golkar semakin intensif dalam mengembangkan atau mengkampanyekan Islam yang sesuai dengan persepsi dan haluan politiknya. ${ }^{40}$

Dengan demikian dapat dipahami bahwa sistem politik yang ada pada sejak zaman penjajahan sampai dengan era orde baru cukup besar pengaruhnya terhadap pelaksanaan sistem pendidikan Islam baik komponen kurikulum dan materi pelajaran dan pengadaan guru maupun kebijakan lain yang menyangkut identitas sebuah lembaga pendidikan Islam. Sehingga ada kesan bahwa lembaga pendidikan Islam harus tunduk terhadap segala kebijakan pemerintah yang berkuasa jika tidak ingin lembaga pendidikan tersebut didiskualifikasi. Inilah salah satu bentuk sistem sentralisasi pendidikan yang berlangsung dalam kurun waktu yang cukup lama dan dampaknya dapat dirasakan sampai saat ini.

2) Pendidikan Agama Pasca Asas Pancasila

Sejalan dengan semakin lemahnya ancaman komunisme, Pancasila berhasil ditempatkan sebagai Asas Tunggal dlam kehidupan berbangsa dan bernegara. Dalam hubungan demikian, tokoh-tokoh Islam memberikan jaminan bahwa Negara Kesatuan Republik Indonesia yang berasaskan Pancasila dan UUD 1945 merupakan bentuk final negara Bangsa Indonesia. 
Persoalannya kemudian adalah, apakah pendidikan agama di sekolah telah kehilangan muatan politik? Istilah "pendidikan agama" itu sendiri memuat dua masalah yang sangat fundamental bagi manusia. Yang pertama adalah masalah "pendidikan" dan yang kedua adalah masalah "agama" yang kedua-duanya secara langsung menyangkut kepentingan umum. Ramainya polemik tentang RUU SPN 1989 yang lalu sebagai bukti bahwa persoalan pendidikan sarat dengan muatan politik.

Dalam UUSPN No. 2 Tahun 1989 pasal 39 ayat 2 ditegaskan bahwa: “Isi kurikulum setiap jenis, jalur dan jenjang pendidikan wajib memuat: Pendidikan Pancasila, pendidikan agama, dan pendidikan kewarganegaraan". ${ }^{41}$ Selanjutnya, GBHN 1993 menegaskan bahwa: "Kurikulum dan isi pendidikan yang memuat pendidikan Pancasila, pendidikan agama dan pendidikan kewarganegaraan terus ditingkatkan dan dikembangkan di semua jalur, jenis dan jenjang pendidikan nasional".

Dari kebijakan politik Pemerintah Orde Baru tentang pendidikan Agama di atas, mengisyaratkan kepada kita bahwa dalam suasana kehidupan sosial ekonomi dan politik yang semakin mantap, justeru menuntut pelaksanaan pendidikan agama semakin intensif dan kualitatif. Tuntutan ini paling tidak berdasarkan pada dua hal berikut: Pertama, agar peserta didik mendapat pemahaman yang semakin kualitatif terhadap fungsi agama bagi kehidupan manusia. Dengan pendidikan agama yang berkualitas diharapkan peserta didik tidak melecehkan nilai-nilai agama yang sarat dengan nilai-nilai kemanusiaan dan amal kebajikan. Kedua, dengan pendidikan agama yang berkualitas diharapkan agar peserta didik mendapat kepuasan moral, sosial dan intelektual dalam beragama, sehingga mereka tidak mencari "menu" yang lain.

Sementara pada pasal 37 ayat 1 UUSPN No. 20 Tahun 2003 ditegaskan bahwa: Kurikulum pendidikan dasar dan menengah wajib memuat: pendidikan agama, pendidikan kewarganegaraan, bahasa, matematika, ilmu pengetahuan alam, ilmu pengetahuan sosial, seni dan budaya, pendidikan jasmani dan olahraga, keterampilan/kejuruan, dan muatan lokal". ${ }^{42} \mathrm{Hal}$ ini mengindikasikan bahwa pendidikan agama menempati posisi yang strategis dalam sistem pendidikan nasional.

Dari penjelasan di atas dapat dipahami bahwa telah terjadi perbedaan sistem pendidikan antara masa orde lama dan orde baru yang identik dengan sistem sentralisasi dengan erde reformasi yang identik dengan sistem desentralisasi. Hal ini seiring dengan tuntutan masyarakat yang begitu kuat terkait dengan munculnya wacana otonomi daerah, sehingga pendidikan pun harus diotonomisasikan.

Selanjutnya, dalam kaitannya dengan sistem pendidikan Islam di era reformasi sekarang ini dapat ditangkap sebuah kesan bahwa pemerintah yang berkuasa berkeinginan agar setiap unsur yang ada pada sebuah lembaga pendidikan harus berdiri pada asas iman dan takwa sebagai tujuan yang harus dicapainya. Tentu saja, hal itu sangat tergantung pada kehendak politik (political will) para pemegang kebijakan di bidang pendidikan. 


\section{Kesimpulan}

Dari uraian di atas dapat dipahami bahwa pendidikan Islam sebagai suatu sistem sangat dipengaruhi oleh sistem-sistem yang ada dalam kehidupan yang meliputi sistem sosial-budaya, ekonomi dan politik. Corak dari masing-masing sistem tersebut akan memberi warna yang signifikan terhadap corak pendidikan Islam yang meliputi komponen tujuan pendidikan Islam, kurikulum, materi, pengadaan guru dan komponen lainnya.

Pada intinya, kesemua sistem tersebut bermuara pada sistem sosial-budaya sebagai penentu kemajuan dan kemunduran dari pendidikan Islam. Artinya, bahwa pola fikir masyarakat yang positif terhadap masalah pendidikan agama akan menjadi penentu sistem ekonomi dan politik dalam memberikan dukungan terhadap pendidikan agama, termasuk kebijakan politik terhadap pendidikan agama juga bermuara pada aspek sosial-budaya. Oleh karena itu, majumundurnya pendidikan Islam sangat ditentukan oleh masyarakat itu sendiri, lebih-lebih para pemegang kebijakan di bidang pendidikan. Kita hanya bisa berharap agar ke depan, para pemegang kebijakan di bidang pendidikan adalah orang-orang yang memiliki kecenderungan kepada Islam atau dalam bahasa lain, orang-orang yang kuat ke-Islam-annya. Amin.

\section{Catatan akhir:}

1 Hasan Langgulung, Peralihan Paradigma dalam Pendidikan Islam dan Sains Sosial, (Jakarta: Gaya Media Pratama, 2002), hal. 12-13

2 Catatan sejarah tentang pendidikan Islam/Muslim memberikan beragam perspektif tentang sifat dan fungsi lembaga tradisionalnya. Penekanan cultural dan politik mengakhiri pendidikan Islam sebagai sistem fungsional yang bertujuan memahami dan menerapkan prinsip pedagogis Alqur'an dan membatasinya pada pengetahuan "agama" yang terbatas pada orang-orang tertentu. Pendidikan Islam belakangan ini dirancukan dengan materi subjek "agama" atau dengan aturan sosial, moral, dan akhlak. Keunggulan pendidikan yuridis dan perumusan atas pengembangan secara informal karakter Islam menghasilkan diferensiasi kurikuler dan instruksional antara kelas dan gender, pemisahan pengetahuan "Islam" dan "non-Islam", dan dikotomi antara ideal dan praktek dalam pendidikan Muslim. Lihat John L. Esposito, Ensiklopedi Oxford Dunia Islam Modern, Perpustakaan Nasional Katalog Dalam Terbitan (KDT), (Bandung: Mizan, 2001), hal. 264.

3 Lihat Undang-undang No. 25 Tahun 2000 tentang Program Pembangunan Nasional (Propenas) Tahun 2000-2004, (Jakarta: Sinar Grafika, 2001), hal. 165.

4 Kata pendidikan, yang dalam bahasa Inggeris "education", dalam bahasa Arab disebut "tarbiyah". Kata tarbiyah, berasal dari kata dasar "rabba-yurabbi" menjadi "tarbiyah", yang berarti tumbuh dan berkembang. Lihat Abu Luwis al-Yasu'i, Al-Munjid Fi al-Lughah Wa al-Munjid Fi al-A'lam, Cet.23 (Beirut: Dar al-Masyriq, tt.), hal. ... Secara umum, pendidikan dapat diartikan sebagai usaha manusia untuk membina kepribadiaannya sesuai dengan nilai-nilai di dalam masyarakat dan kebudayaan. Tim Dosen FIP IKIP Malang, Kapita Selekta-Pengantar Dasar-dasar Kependidikan, (Malang: IKIP Malang, 1981), hal. 2. Bagi umat Islam, agama merupakan dasar utama dalam mendidik anak-anaknya melalui sarana-sarana pendidikan. Karena dengan menanamkan nilai-nilai agama akan sangat membantu terbentuknya sikap dan kepribadian anak kelak pada 
masa dewasa. Dengan demikian dapat dikatakan bahwa pendidikan Islam adalah usaha yang diarahkan kepada pembentukan kepribadian anak yang sesuai denga ajaran Islam atau suatu upaya dengan ajaran Islam, memikir, memutuskan dan berbuat berdasarkan nilai-nilai Islam, serta bertanggung jawab sesuai dengan nilai-nilai Islam. Zuharaini, dkk., Filsafat Pendidikan Islam, (Jakarta: Bumi Aksara, 1991), hal. 152.

5 Sebagaimana tercermin dalam Pembukaan UUD 1945; “Untuk memajukan kesejahteraan umum dan mencerdaskan kehidupan bangsa". Lihat UUD 1945 Hasil Amandemen, (Jakarta: Sinar Grafika, 2002), hal. 3.

${ }^{6}$ Amanat pasal 31 UUD1945 tersebut dan perubahannya menyebutkan bahwa; "(1) Tiap-tiap warga negara berhak mendapatkan pendidikan; (3) Pemerintah mengusahakan dan menyelenggarakan satu sistem pendidikan nasional yang meningkatkan keimanan dan ketakwaan, serta akhlak mulia dalam rangka mencerdaskan kehidupan bangsa yang diatur dengan undang-undang". Ibid., hal. 25.

7 Sebagaimana yang terlihat pada pasal 1 ayat 5 UUSPN 2003 yang menyebutkan bahwa: "Pendidikan Nasional adalah pendidikan yang berdasarkan Pancasila dan Undang-Undang Dasar Negara Republik Indonesia Tahun 1945 yang berakar pada nilainilai agama, kebudayaan nasional Indonesia dan tanggap terhadap tuntutan perubahan zaman. Lihat Undang-undang RI No. 20 Tahun 2003 tentang Sistem Pendidikan Nasional, (Jakarta: Eko Jaya, 2003), hal. 5. Dan pasal 4 UUSPN 2003, yaitu: "Pendidikan nasional bertujuan mengembangkan potensi peserta didik agar menjadi manusia beriman dan bertakwa kepada Tuhan Yang Maha Esa, berakhlak mulia, berbudi mulia, sehat, berilmu, kompeten, terampil, kreatif, mandiri, estetis, demokratis, dan memiliki rasa kemasyarakatan dan kebangsaan". Serta pada pasal 13 ayat 1 huruf A UUSPN 2003, yaitu: "Setiap peserta didik pada setiap satuan pendidikan berhak mendapat pendidikan agama sesuai dengan agama yang dianutnya dan diajarkan oleh pendidik yang seagama".

8 Pendidikan agama berbeda dengan pendidikan Islam sekalipun ia mmempertahankan sisa-sisa lembaga pendidikan Islam. Dengan memisahkan pengetahuan "wahyu" dan pengetahuan "manusia", prinsip Alqur'an ditransformasi menjadi aturan hokum dan moral serta ritual yang terumuskan, yang menciptakan dikotomi dalam pemikiran Islam. Demikian juga makna dictum Nabi "Faqqihhu fi alDin" (Shahih Muslim) mengalami transformasi, dari mengajar di dalam pandangandunia Islam ke mengajar Islam seperti yang ditafsirkan oleh berbagai mazhab fikih. Lihat John Esposito, Loc. Cit.

${ }^{9}$ Lihat Q.S. Luqman ayat 13 artinya: "Dan ingatlah ketika Luqman berkata kepada anaknya di waktu ia memberi pelajaran kepadanya. Hai anakku, janganlah kamu mempersekutukan Allah, sesungguhnya mempersekutukan Allah adalah benar-benar kezaliman yang besar". Pendidikan yang pertama dan utama untuk dilakukan adalah pembentukan keyakinan kepada Allah yang diharapkan dapat melandasi sikap, tingkah laku dan kepribadian anak didik. Dan ayat 14,18 dan 19 yang artinya: " Dan Kami perintahkan kepada manusia untuk berbuat baik kepada dua orang ayah ibunya, ibunya yang telah mengandungnya dalam keadaan lemah yang bertambah-tambah dan menyapihnya dalam dua tahun. Bersyukurlah kepada-Ku dan kedua orang ayah ibumu, hanya kepa-Kulah kembalimu. Dan janganlah kamu memalingkan mukamu dari manusia karena sombong dan janganlah kaamu berjalan di muka bumi dengan angkuh.Sesungguhnya Allah tidak menyukai orang-orang yang sombong lagi membanggakan diri. Dan sederhanakanlah kamu dalam berjalan, dan lunakkanlah suaramu. Sesungguhnya seburuk-buruk suara ialah suara keledai". Akhlak termasuk di antara makna yang terpenting dalam hidup ini. Tingkatnya berada sesudah keimanan/kepercayaan keapada Allah, malaikat-Nya, Rasul-Nya, hari akhirat yang 
terkandung hasyar, hisab, balasan akhirat dan kada dan kadar Allah. Juga terletak sebuah ibadat kepada Allah, mentaati-Nya, ikhlas kepada-Nya, dan menyerahkan diri kepada-Nya. Apabila keimanan berkaitan erat dengan hubungan hamba dengan TuhanNya, maka akhlak berkaitan erat dengan hubungan manusia dengan sesama, bahkan dengan segala yang terdapat dalam wujud dan kehidupan ini. Dan selanjutnya ayat 17 yang artinya: "Hai anakku, dirikanlah shalat dan suruhlah (manusia) mengerjakan yang baik dan cegahlah mereka dari perbuatan yang mungkar dan bersabarlah terhadap apa yang menimpa kamu. Sesungguhnya yang demikianlah itu termasuk hal-hal yang diwajibkan Allah". Ibadah yang secara awam diartikan sesembahan, pengabdian, sebenarnya adalah istilah yang paling luas dan mencakup tidak hanya penyembahan, tetapi juga berhubungan dengan laku manusia meliputi kehidupan. Yang paling beradab, dari segi pandangan spiritual, adalah mereka yang mematuhi dengan sangat rapat kemauan Tuhan, di dalam semua perbuatan-perbuatan mereka.

10 Menurut Jusuf Amir Feisal, bahwa sistem pendidikan Islam itu hendaknya memadukan pendekatan normatif-deduktif (bersumber pada Alqur'an dan Sunnah serta Sunnatullah) dengan pendekatan deskriptif-induktif (sesuai dengan cita-cita kemerdekaan) yang meliputi: Dasar, tujuan, fungsi, kelembagaan, dan struktur pendidikan yang Islami. Lihat Jusuf Amir Feisal, Reorientasi Pendidikan Islam, (Jakarta: Gema Insani Press, 1995), hal. 116.

11 Sedangkan budaya itu sendiri didefinisikan sebagai tatanan pengetahuan, kepercayaan, nilai, sikap, makna, hirarki, agama, waktu, peranan, hubungan ruang, konsep alam semesta, objek-objek materi dan milik yang diperoleh sekelompok besar orang dari generasi ke generasi melalui usaha individu dan kelompok. Lihat Richard E. Porter \& Lary A. Samoar dalam Deddy Mulyana, Jalaluddin Rakhmat, editor, Komunikasi Antar Budaya, (Bandung: Remaja Rosdakarya, 2000), hal. 18.

${ }^{12}$ Agama, dalam hal ini adalah agama yang lahir dari kecerdasan spiritual dalam kehidupan masyarakat, termasuk salah satu aspek budaya. Dalam hal ini tentu saja, bukan agama yang diwahyukan oleh Al-Khalik Yang Maha Kuasa, yang termasuk tatanan "supra-sistem". Lihat Nursyid Sumaatmadja, Pendidikan Pemanusiaan Manusia Manusiawi, (Bandung: Alfabeta, 2002), hal. 17.

${ }^{13} \mathrm{Ibid}$.

14 Ibid, hal. 21.

${ }^{15}$ Nasikun, Sistem Sosial Indonesia, (Jakarta: Raja Grafindo Persada, 1995), hal. 12.

16 Achmad Jainuri, Pendidikan dan Modernisasi di Dunia Islam, (Surabaya: Al-Ikhlas, 2001), hal. 4-5.

17 Ibid.

18 Albert Hasibuan, Modernisasi Indonesia dan Usaha Mencegah dan Mengatasi Kemacetan Faktor-faktor Pembangunan, dalam; Demokratisasi Politik, Budaya dan Ekonomi; Pengalaman Indonesia Masa Orde Baru, (Jakarta: Yayasan Paramadina, 1994), hal. 27.

19 Lihat Mastuhu, Memberdayakan Sistem Pendidikan Islam; Strategi Bedaya Menuju

Masyarakat Akademik, (Jakarta: Logos Wacana Ilmu, 1999), hal. 44.

${ }^{20}$ Achmad Jainuri, Op. Cit., hal. 89.

21 Menurut para ahli, perkataan ekonomi berasal dari bahasa Yunani, yaitu oicos yang berarti rumah, dan nomos yang berarti aturan. Lihat Abdullah Zaky al-Kaaf, Ekonomi Dalam Perspektif Islam, (Bandung: Pustaka Setia, 2002), hal. 18

22 Ibid., hal. 19.

${ }^{23}$ M. Quraish Shihab, Wawasan Al-Qur'an; Tafsir Maudhu'i Atas Pelbagai Persoalan Umat, (Bandung: Mizan, 1998), hal. 402.

${ }^{24}$ Lihat Kuntowijoyo, Identitas Politik Umat Islam, (Bandung: Mizan, 1997), hal. 136. Uraian tentang keempat aksioma tersebut adalah: Pertama, etika tauhid menekankan 
kepada aspek bahwa manusia adalah makhluk Ilahiyyah yang berarti bahwa manusia harus meniru akhlak Tuhan dan bersifat integrative yang berarti bahwa antara satu dengan yang lainnya tidak dapat dipisahkan. Kedua, etika keseimbangan yang berarti bahwa manusia tidak boleh berlebih-lebihan dalam mengejar kepentingan ekonomi. Ketiga, etika kehendak bebas yang berarti bahwa manusia memiliki kebebasan untuk menentukan nasibnya sendiri, termasuk mengaplikasikan kaidah-kaidah Islam dalam ekonomi. Keempat, etika pertanggungjawaban yang menekankan kepada sikap melaksanakan tanggung jawab (amanah) dan diperhitungkan (accountability).

${ }^{25}$ Abdullah Zaky al-Kaaf, Op. Cit., hal. 128

${ }^{26}$ Lihat UUD 1945 Pasal 33.

27 Lihat Ramayulis, Reaktualisasi Pendidikan Islam dalam Konteks Kekinian dan Kedisinian (Makalah Seminar Internasional Reformulasi Pendidikan Islam Menghadapi Pasar Bebas) dalam rangka Pembukaan Program Doktor (S3) Pascasarjana IAIN Imam Bonjol Padang, 12 Pebruari 2005, hal. 4.

28 Ibid., hal. 10.

${ }^{29}$ Lihat Maidir Harun, Pendidikan di Minangkabau; Sejarah, Kenyataan dan Harapan, (Makalah Seminar Internasional Reformulasi Pendidikan Islam Menghadapi Pasar Bebas) dalam rangka Pembukaan Program Doktor (S3) Pascasarjana IAIN Imam Bonjol Padang, 12 Pebruari 2005, hal. 10.

30 Perkataan politik berasal dari bahasa Latin Politicus dan bahasa Yunani Politicos, artinya (sesuatu yang) berhubunga dengan warga negara atau warga kota. Kedua kata itu berasal dari kata polis maknanya kota. Lihat Tim Penyusun, Kamus Besar Bahasa Indonesia, Cet. II, (Jakarta: Balai Pustaka, 1989), hal.

${ }^{31}$ Beberapa penulis memberi definisi istilah ini lebih luas yang mencakup hampir setiap hubungan sosial yang menggunakan pengaruh dan yang mengambil keputusankeputusan otoritatif. Jadi, di dalam kelompok-kelompok sub-masyarakat seperti keluarga, gereja, serikat buruh, atau organisasi usaha, struktur pengambilan keputusan kelompok dianggap sebagai sistem politik. Lihat Jack J. Plano, dkk., The Dictionary of Political Analysis (Kamus Istilah Politik), terj. Edi S. Siregar, (Jakarta: Rajawali, 1985), hal. 179.

32 Mohammad Daud Ali, Pendidikan Agama Islam, (Jakarta: Raja Grafindo Persada, 2004), hal. 167.

${ }^{33}$ Lihat Masykuri Abdillah, Demokrasi Di Persimpangan Makna; Respons Intelektual Muslim Indonsia Terhadap Konsep Demokrasi (1966-1993), (Yogyakarta: Tiara Wacana, 1999), hal. 72.

34 Ibid., hal. 74

35 Tobroni dan Syamsul Arifin, Islam Pluralisme Budaya dan politik; Refleksi Teologi Untuk Aksi Dalam Keberagamaan dan Pendidikan, (Yogyakarta: Sipress, 1994), hal. 123

36 Achmad Jainuri, Op. Cit., hal. 14-15

37 Karel A. Steenbrink, Pesantren, Madrasah, Sekolah: Pendidikan Islam dalam Kurun Modern, (Jakarta: LP3ES, 1986), hal.

38 Tobroni, Op. Cit., hal. 124

39 A. Syafi'i Ma'arif, Islam dan Politik di Indonesia pada Masa Demokrasi Terpimpin (1959-1964), (Yogyakarta: IAIN Sunan Kalijaga Press, 1988), hal.

40 Upaya Golkar di atas dilakukan misalnya dengan mendirikan GUPPI, MDI, YAMP, BAZIZ dan lain sebagainya. Walaupun aktifitas keislaman yang dilakukan Golkar itu pada mulanya lebih bersifat politis atau minimal sarat dengan muatan politis, akan tetapi ternyata memiliki hikmah tersendiri bagi kehidupan keagamaan dalam era Orde Baru ini. 
Al-Fikra: Jurnal Ilmiah Keislaman, Vol. 4, No. 2, Juli-Desember 2005

${ }^{41}$ Lihat Undang-Undang No. 2 Tahun 1989 tentang Sistem Pendidikan Nasional. Dalam penjelasannya terhadap pasal tersebut antara lain dijelaskan bahwa pendidikan agama merupakan usaha untuk memperkuat iman dan ketakwaan kepada Tuhan Yang Maha Esa sesuai dengan agama yang dianut peserta didik yang bersangkutan dengan memperhatikan tuntutan untuk menghormati agama lain dalam hubungan kerukunan antar umat beragama dalam masyarakat untuk mewujudkan persatuan nasional.

${ }^{42}$ Lihat UUSPN Tahun 2003, Op. Cit., hal. 21 